\section{Court ruling sounds note of caution for sonar system}

Rex Dalton, San Diego

A court has ordered the US Navy to come up with an environmental plan before it extends the deployment of a submarinedetection system that some biologists say could disturb and harm marine mammals and fish.

The ruling by a federal judge in San Francisco could end a prolonged wrangle between the navy and environmentalists over the use of the sonar system (see Nature 413, 243; 2001).

Environmental groups and the navy will meet on 7 October to work out terms for deploying the new sonar, which emits a low-frequency, 140-decibel sound wave that is able to pick up echoes from submarines hundreds of kilometres away.

On 26 August, Judge Elizabeth Laporte of the US District Court in San Francisco ruled that the navy did not have proper environmental permits to test and use the sonar system widely. Environmentalists greeted the ruling as a major victory in their long-running efforts to block its deployment. The navy, even as it complies with the ruling, will push Congress to change the law.

In her 73-page ruling, Laporte said that the case required a difficult balancing act between national security requirements and laws enacted to protect sea life. She declined to ban the sonar outright, but sought a permanent, court-approved plan to allow broader use of the equipment while protecting sea life.

The decision "recognizes that during peacetime even the military must comply with our environmental laws", says Joel Reynolds, a senior attorney for the Washington-based National Resources Defense Council, the environmental group that led the lawsuit. The navy said that it was "concerned about the implications of the decision for national defence".

Currently, the navy can only test and train with the new sonar system in a region covering two million square kilometres near Guam in the western Pacific Ocean. But the navy wants to use it in ocean habitats that are populated by whales and other species that are already suffering environmental pressures.

Other sonars that operate at higher frequencies have been linked to incidents in which whales, dolphins or porpoises were harmed or killed (see Nature 415, 106; 2002).

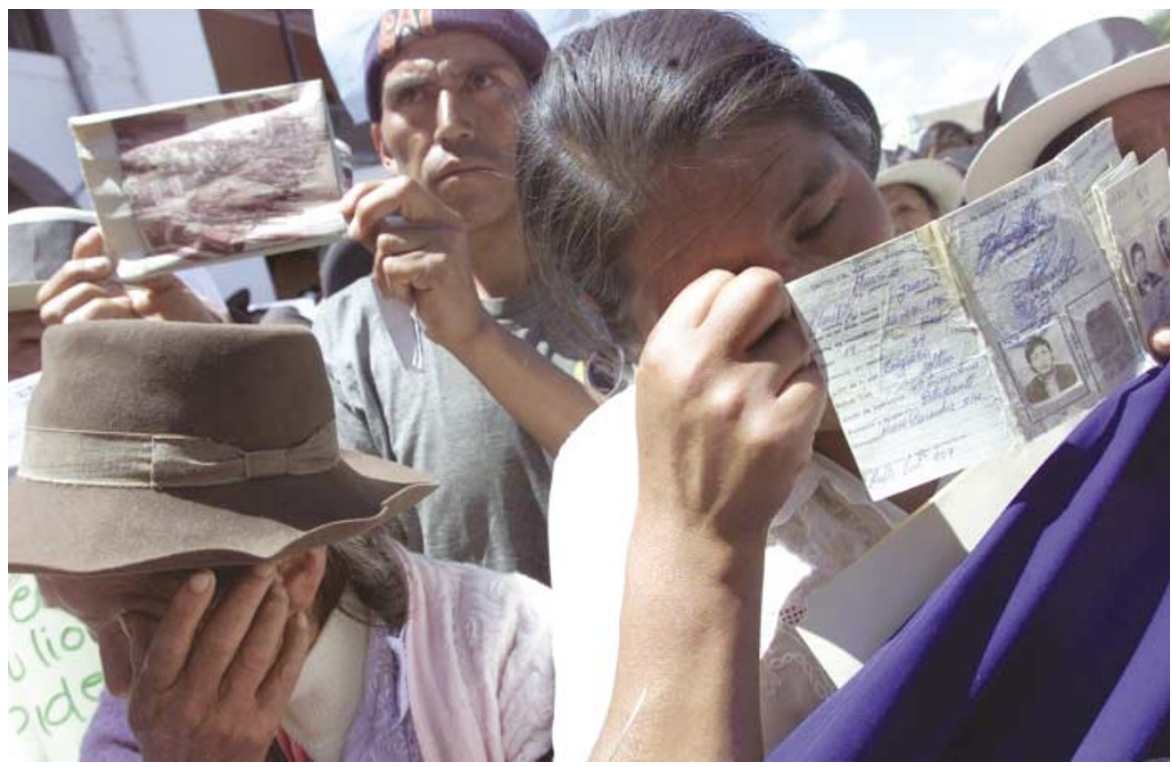

Relatives gathered in Ayacucho last week to hear Truth Commission findings on Peru's years of conflict.

\title{
Statistical model leaves Peru counting the cost of civil war
}

Jonathan Knight, San Francisco

A statistical method for estimating animal populations is proving increasingly useful in documenting human-rights abuses. Its latest achievement, revealed last week, was to reconcile conflicting accounts of the death toll from two decades of civil war in Peru.

Up to 35,000 people were believed to have been killed in a conflict that raged between the government and Shining Path Maoist insurgents from 1980 until about 2000. The new analysis, part of the final report from Peru's Truth and Reconciliation Commission delivered in Lima on 28 August, concludes that more than 69,000 people died. Of these, $46 \%$ were killed by the Shining Path, $30 \%$ by the government, and the rest by other rebels and paramilitary groups.

"As soon as people hear these numbers, they ask how could it have been so many, and why did they have no idea," says sociologist Patrick Ball, the study's lead author and deputy director of the Science and Human Rights Program at the American Association for the Advancement of Science (AAAS).

Accurate death counts during civil conflicts are hard to come by. Bodies may be disposed of anonymously in mass graves, and witnesses may distrust investigators. In Peru, much of the killing took place in remote villages in the Andes.

Ball and his colleagues applied a statistical method developed in the late nineteenth century to count wild animals. It has since been used to adjust census estimates of hardto-count groups such as the homeless.

Multiple-systems estimation (MSE) relies on the existence of overlapping partial counts of a population. The principle is that the chance of an individual appearing on two lists is equal to the product of their chances of appearing on each list separately. Ball's team compared seven lists of dead and missing people compiled since 1980 .

The researchers had to factor in potential sources of bias. For example, one public agency was charged with collecting testimony about abuses by the military, so its databases contained little about murders by rebels. Yet its statistics had been touted as evidence that the government did most of the killing. "People weren't thinking like statisticians," says Ball. "They were throwing the numbers around without thinking about the process."

This is not the first time MSE has proved its worth. In 1999, Ball wrote a AAAS report on the 1981-83 conflict in Guatemala which revealed a disproportionate number of deaths among people of Mayan descent, ultimately leading a United Nations commission to conclude that the Guatemalan army had engaged in genocide. Last year Ball testified at the trial of former Yugoslav president Slobodan Milosevic that the same method confirmed the Yugoslav army as responsible for the deaths of thousands of Albanians in Kosovo in 1999.

Although many leaders of the Shining Path are already dead or in jail, the military has never been held accountable, says Sergio Meza, head of the Peruvian section of Amnesty International: "We now have the opportunity to prosecute those members of the military who violated human rights." But there is strong political and military opposition to such prosecutions. 